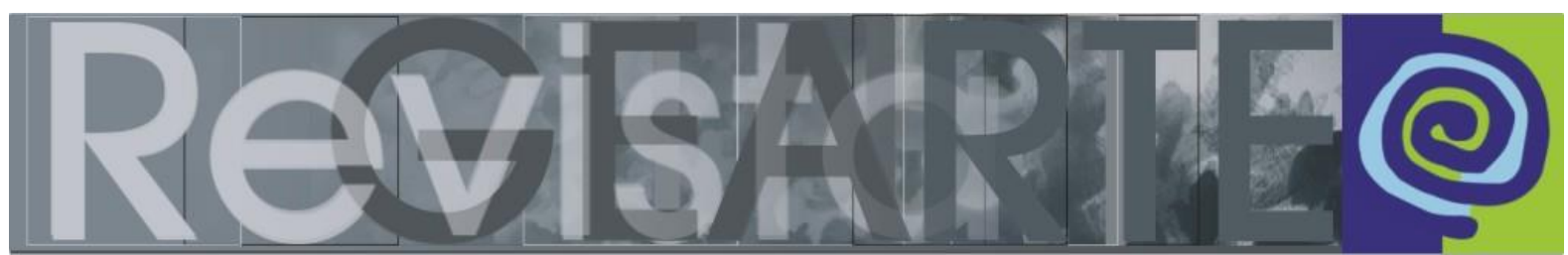

ISSN 2357-9854 | e-ISSN 2596-3198 (online)

\title{
Discurso de abertura do Congresso de Ensino/Aprendizagem das Artes na América Latina: Colonialismo e Questões de Gênero
}

\author{
Danilo Santos de Miranda \\ (Diretor Regional do Serviço Social do Comércio no estado \\ de São Paulo — Sesc São Paulo, São Paulo/SP, Brasil)
}

"Tratar dos processos de ensino e aprendizagem num congresso de Arte/Educação nos convoca a enfrentar a problemática da transmissão de conhecimentos e tradições.

Noção controversa no debate educacional, transmissão pode ser compreendida de maneiras distintas, conforme seus diferentes significados no processo histórico: por um lado, como compartilhamento, por outro, como imposição pura e simples.

Nos empreendimentos coloniais do passado, e também nas novas formas de colonização, é da segunda acepção que se trata, tendo em vista os mecanismos de aculturação, disciplinamento e dominação que integram suas bases de operação.

Hábil em desenvolver nossas capacidades, as artes e as pedagogias a elas atreladas representam um campo propício ao questionamento das imposições culturais.

Mais do que isso, elas favorecem a experimentação de dinâmicas de compartilhamento voltadas à construção conjunta de conhecimentos, a partir do contato com referências e tradições diversas.

Contudo, a vigência de processos desse tipo nos âmbitos formal e não formal da educação brasileira ainda enfrenta ameaças, como atestam a recente desobrigação da disciplina de Arte no currículo do Ensino Médio e, também, as dificuldades enfrentadas pelas instituições culturais no país. 


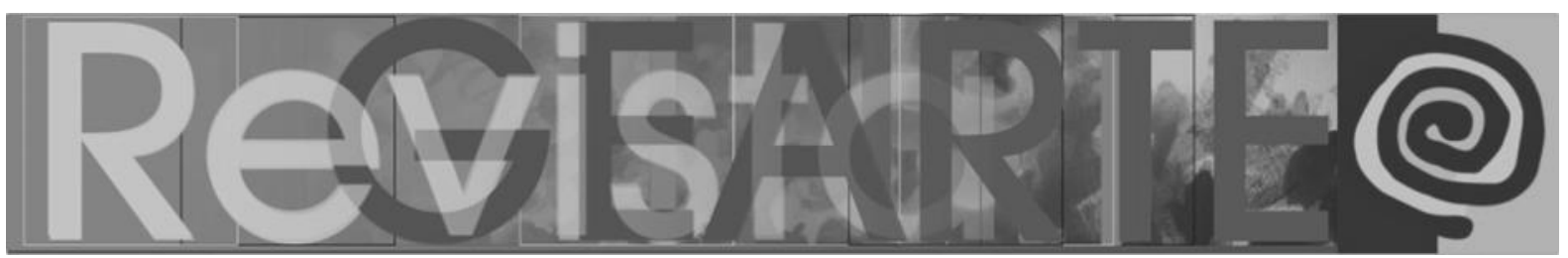

Consciente do papel estratégico desempenhado pelas artes na formação do sujeito, assim como na contestação de conservadorismos e injustiças, o Sesc realiza sua ação sociocultural de forma articulada com as linguagens artísticas contemporâneas.

Essa opção baseia-se no entendimento de que tais linguagens são afeitas à interdisciplinaridade e ao entrecruzamento de saberes múltiplos, produzindo efeitos pelo viés sensível.

Refletir com o devido rigor sobre esses e outros aspectos do ensino de arte corresponde, no limite, a afirmá-los como ferramentas e valores inegociáveis!"

\section{Danilo Santos de Miranda}

Estudou Filosofia, Ciências Sociais e Administração. Especialista em gestão empresarial pelo International Institute for Management Development (IMD), na Suíça. É diretor geral do Serviço Social do Comércio (Sesc) no estado de São Paulo desde 1984. É membro do conselho de entidades nacionais como a Fundação Bienal de São Paulo, o Museu de Arte de São Paulo Assis Chateaubriand (MASP), o Museu de Arte Moderna de São Paulo (MAM), o Itaú Cultural, a Biblioteca Brasiliana Guita e José Mindlin e a SP Escola de Teatro. Foi presidente do Conselho Diretor do Fórum Cultural Mundial (2004) e presidente da comissão que organizou o Ano da França no Brasil (2009).https://pt.wikipedia.org/wiki/Danilo Santos de Miranda - cite note-2 Sua atuação internacional também abrange a vice-presidência do Conselho Internacional de Bem-Estar Social (ICSW), de 2008 a 2010, além da composição da diretoria da ONG Art for the World, sediada na Suíça e dedicada à difusão da arte contemporânea. Organizador de livros como "Ética e Cultura", é reconhecido nacional e internacionalmente pelo trabalho que realiza à frente do Sesc São Paulo.

E-mail: danilo@sescsp.org.br

Currículo: www.revistas.usp.br/organicom/article/download/139075/134424/

MIRANDA, Danilo Santos de. Discurso de abertura do Congresso de Ensino/Aprendizagem 